\title{
Effects of amantadine on behavior, respiratory chain enzymes and creatine kinase in an animal model of schizophrenia
}

\section{Efeitos da amantadina sobre o comportamento, as enzimas da cadeia respiratória e da creatina quinase em um modelo animal de esquizofrenia}

Gabriel Rodrigo Fries ${ }^{1,2,3}$, Camila Lersch ${ }^{3}$, Leila Canever ${ }^{4}$, Renata D. de $\mathrm{Luca}^{4}$, Giseli Daiane $\mathrm{Bez}^{4}$, Isabela Casagrande Jeremias ${ }^{4}$, Emilio L. Streck ${ }^{4}$, Alexandra L. Zugno ${ }^{4}$, Danielle Macedo ${ }^{6}$,Clarissa S. Gama ${ }^{1,3,5}$, David F. de Lucena ${ }^{1,3,5,6}$

1. Laboratory of Molecular Psychiatry, Hospital de Clínicas de Porto Alegre, Rua Ramiro Barcelos, 2350, 90035-903, Porto Alegre, RS, Brazil, 2. Programa de Pós-Graduação em Ciências Biológicas: Bioquímica, Universidade Federal do Rio Grande do Sul, Rua Ramiro Barcelos, 2600, Porto Alegre, RS, Brazil, 3. National Institute of Science and Technology for Translational Medicine (INCT-TM), Brazil, 4. Universidade do Extremo Sul Catarinense, 88806-000, Criciúma, SC, Brazil, 5. Programa de Pós-Graduação em Ciências Médicas: Psiquiatria, Universidade Federal do Rio Grande do Sul, Rua Ramiro Barcelos, 2400, Porto Alegre, RS, Brazil, 6. Universidade Federal do Ceará, Departamento de Fisiologia e Farmacologia, Laboratório de Neurofarmacologia.

\begin{abstract}
Introduction: Glutamate dysregulation may be involved in the physiology of schizophrenia, and NMDA antagonists seem to be effective in its treatment. Our group studied the efficacy of amantadine (AMA) in preventing ketamine (KET)-induced effects in an animal model of schizophrenia. Methods: Adult Wistar rats received $10 \mathrm{mg} / \mathrm{kg}$ AMA for 10 days, followed by 7 days of $25 \mathrm{mg} / \mathrm{kg}$ KET ip. Thirty minutes after the last injection, rats were placed in an open-field apparatus for 60 minutes and killed by decapitation afterwards. Amygdala, hippocampus, prefrontal cortex and striatum were isolated and analyzed for creatine kinase (CK) and respiratory chain enzyme activities. Results: KET increased crossings and reduced grooming, which was not prevented by AMA. KET also increased stereotypic movements, which was partially prevented by AMA. As for CK activity, KET increased it in the prefrontal cortex, striatum and amygdala, and AMA prevented it only in prefrontal cortex and striatum. The activity of complex I was not altered by KET, however, AMA+KET increased it in the striatum and amygdala. KET increased the activity of complex II in the striatum as well, whereas AMA+KET increased it in hippocampus, prefrontal cortex, and striatum. KET did not alter complex I-III activity, whereas AMA+KET increased it in hippocampus and amygdala. AMA+KET also increased complex IV activity in hippocampus and striatum, whereas KET had no effect on this activity. Conclusion: AMA did not prevent most of KET-induced alterations. New animal models should be employed in the study of AMA as a potential novel drug for schizophrenia.
\end{abstract}

Keywords: Amantadine. Schizophrenia. Creatine kinase. Respiratory chain enzymes. Mitochondria.

\section{Resumo}

Introdução: A desregulação glutamatérgica pode estar envolvida na fisiopatologia da esquizofrenia, e antagonistas de NMDA parecem ser efetivos no seu tratamento. Nós avaliamos a eficácia da amantadina (AMA) em prevenir efeitos induzidos pela quetamina (KET) em um modelo animal de esquizofrenia. Métodos: Ratos Wistar adultos receberam $10 \mathrm{mg} / \mathrm{kg}$ de AMA por 10 dias, seguidos de 7 dias de KET $25 \mathrm{mg} / \mathrm{kg}$ ip. Trinta minutos após a última injeção, os ratos foram posicionados em um campo aberto por 60 minutos, seguido de decapitação. Amígdala, hipocampo, córtex pré-frontal e estriado foram isolados e analisados para creatina quinase e atividade das enzimas da cadeia de transporte de elétrons. Resultados: A KET aumentou os cruzamentos e o comportamento de grooming, o que não foi prevenido pela AMA. KET também aumentou os movimentos estereotípicos, o que foi parcialmente prevenido pela AMA. KET aumentou a atividade da creatine quinase no córtex pré-frontal, estriado e amígdala, tendo sido prevenida pela AMA apenas no córtex pré-frontal e estriado. A atividade do complexo I não foi alterada pela KET; no entanto, AMA+KET aumentaram esse parâmetro no estriado e na amígdala. KET aumentou a atividade do complexo II no estriado, enquanto AMA+KET a aumentaram no hipocampo, córtex pré-frontal e estriado. KET não alterou a atividade do complexo I-III, enquanto AMA+KET a aumentaram no hipocampo e amígdala. AMA+KET também aumentaram a atividade do complexo IV no hipocampo e estriado, enquanto KET não teve efeitos na sua atividade. Conclusão: AMA não preveniu a maioria das alterações induzidas pela KET. Novos modelos animais deverão ser utilizados para estudar a AMA como uma nova droga para esquizofrenia.

Palavras-chave: Amantadina. Esquizofrenia. Creatina quinase. Enzimas da cadeia respiratória. Mitocôndria.

Correspondência: Gabriel Rodrigo Fries, gabrielrfries@gmail.com, Tel.: +55 51 33598021, Fax: +55 51 33598846. Ramiro Barcelos Street. \#2350, Zip Code: 90035-903, Porto Alegre/RS, Brazil.

Conflito de Interesses: Other authors declare no conflict of interest.

Financial support: This study was supported by grants from CNPq (Universal 470326/2011-5 and PQ 302195/2011-4), FAPERGS (PqG 100934006/2010) and FAPERGS/CNPq (PRONEM 11/2057-2), Brazil. These agencies had no role in the study design, in the acquisition or interpretation of the data, or in writing the report. GRF is supported by a doctorate scholarship from Coordenação de Aperfeiçoamento de Pessoal de Nível Superior (CAPES), Brazil.

Received 18 Sep 2012; Revised 30 Oct 2012; Accepted 29 Nov 2012. 


\section{Introduction}

Schizophrenia (SZ) is a highly debilitating psychiatric disorder with an estimated prevalence of approximately $1-1.5 \%{ }^{1}$. Its presentation includes positive symptoms (hallucinations and delusions), negative symptoms (social withdrawal, affective flattening, avolition and blunted affect) and cognitive impairments ${ }^{2}$. Treatment of patients with SZ includes acute and maintenance management, including a wide range of typical and atypical antipsychotics whose efficacy is not generalized among patients ${ }^{3}$. Effective maintenance treatment can decrease the frequency and the severity of the illness' episodes, reduce its morbidity and mortality, and maximize the psychosocial functioning and the quality of life of patients ${ }^{3}$. Nevertheless, several patients are refractory to medication, and some of the symptoms persist even when the adherence is considered good $^{4}$. In this sense, further studies are warranted in the search for novel and more effective drugs for the maintenance treatment of SZ.

Despite several studies attempting to search the neurobiological underpinnings of $\mathrm{SZ}$, its pathophysiology is not completely understood. It seems to include a wide range of mechanisms, from genetic markers to oxidative stress ${ }^{5-11}$. Neuroanatomical findings report a decrease in whole brain and grey matter volume ${ }^{12-15}$, as well as a progressive increase in ventricular and cortical cerebrospinal fluid volumes in first-episode schizophrenic patients ${ }^{13-16}$. Taken together, these findings suggest the occurrence of neurodegenerative-like mechanisms in patients.

Among possible mechanisms leading to neuronal damage, disturbs in brain energy metabolism have been reported as important factors ${ }^{17}$. Impaired energy metabolism can lead to neuronal death by decreasing ATP levels and ultimately leading to apoptosis ${ }^{18}$. Of note, mitochondrial dysfunction with subsequent alterations in respiratory chain complexes has been implicated in the pathophysiology of $\mathrm{SZ}^{19,20}$. Briefly, it includes mitochondrial hypoplasia, altered mitochondrialrelated gene expression, and impairment of the oxidative phosphorylation system in patients ${ }^{21,22}$. Moreover, abnormal mitochondrial morphology, proportion and density have already been found in the brain of individuals with $\mathrm{SZ}^{20}$. Energy metabolism parameters include the assessment of mitochondrial respiratory chain enzymes and creatine kinase (CK) activity, which participate in energy homeostasis and indicate the level of ATP demand in a sample. In this vein, evidences suggest that known antipsychotic drugs modulate mitochondrial functions ${ }^{23}$, suggesting the importance of enhancing mitochondrial parameters in the effective treatment of SZ.

Given the complexity of the disorder and the need for further understanding its neurobiology, different animal models of SZ have been employed ${ }^{24}$. In rats and monkeys, noncompetitive NMDA antagonists, including phencyclidine and ketamine (KET), produce a range of behavioral abnormalities that resemble symptoms of SZ in humans ${ }^{25,26}$. Treatment with KET has been shown to cause individual psychosis in patients with $\mathrm{SZ}$ in symptom remission ${ }^{27-29}$, and the use of this substance is also employed to assess positive and negative symptoms in healthy volunteers ${ }^{30}$. We and others have used a chronic treatment with subanesthetic doses of KET in rats as an animal model of $\mathrm{SZ}^{26,31-33}$. In this model, KET has been shown to induce stereotypic movements and significant social deficits in different treatment schemes ${ }^{32-34}$. Altogether, this model has been shown to present predictive, construct and face validity ${ }^{26,35,36}$, and allows for its use in testing novel potential drugs for SZ.

Among newly tested drugs, memantine, a weak nonselective NMDA receptor antagonist, has been reported to improve cognitive, positive and negative symptoms on a randomized placebo-controlled clinical trial as adjunctive to clozapine for treatment-refractory patients with $\mathrm{SZ}^{37}$. More recently, amantadine (AMA), a memantine's derivate, has improved clinical response to negative symptoms in a case series ${ }^{38}$, and was effective in the treatment of five patients with SZ or schizoaffective disorder (SZA) and acute catatonia ${ }^{39}$. AMA may act like memantine by chronically reducing neuronal oxidative stress of treated patients, thus decreasing aggression to neurons and neuronal death, as well as modulating mitochondrial functions ${ }^{40}$.

Based on previous findings, AMA may be a promising drug to be further tested in SZ. A better understanding of its mechanism of action in preclinical studies may point to relevant targets in SZ and to the proposal of novel potential drugs for its treatment. To that end, we aimed to evaluate the efficacy of AMA in preventing the effects of KET on behavior, mitochondrial respiratory chain enzymes and CK activity in an animal model of SZ.

\section{Materials and methods}

This study was approved by our local ethics committee and performed in accordance with the recommendations of NIH Guide for the Care and Use of Laboratory Animals and Sociedade Brasileira de Neurociências e Comportamento (SBNeC).

\section{Animals}

Adult male Wistar rats (weight 250-300 g) were obtained from our breeding colony (Central Animal House of Universidade do Extremo Sul Catarinense) and caged in groups of five with food and water available ad libitum. They were maintained on a 12-h light/dark cycle (lights on at 7:00 am), at a temperature of $22^{\circ} \mathrm{C} \pm 1$ 으.

\section{Treatment}

AMA was administered ip at $10 \mathrm{mg} / \mathrm{kg}$ for 10 days, followed by 7 days of subanesthetic ip administrations of $25 \mathrm{mg} / \mathrm{kg}$ KET $(31,41)$. Saline $(S A L)$ injections were performed as 
controls for both AMA and KET, totalizing four experimental groups ( $n=12$ per group): $S A L+S A L, S A L+K E T, A M A+S A L$, and $A M A+K E T$. Thirty minutes after the last injection, rats were placed in an open-field apparatus and evaluated as described below.

\section{Behavioral evaluation}

\section{Open-field task}

Locomotor activity was assessed in a $50 \times 25 \times 50 \mathrm{~cm}$ openfield surrounded by walls made of brown plywood with a frontal glass wall. The floor of the arena was divided into 12 equal rectangles by black lines. The animals were gently placed on the left rear rectangle and were allowed to explore the arena for 60 minutes. Locomotor activity was constantly monitored by a system installed in the arena containing six parallel bars, each of which contained 16 infrared sensors that detect the rat's exact position and movement, enabling a detailed analysis of each animal's behavior. Information detected by the sensors is transmitted to a computer in which the animal's activity is recorded for $5 \mathrm{~min}$ by a dedicated software (database: Open Source version Interbase 6.01). Number of crossings and grooming behavior were counted.

\section{Stereotypy}

Stereotypy was defined as rapid, repetitive head and forelimb movements. This parameter was analyzed at the same time and place as the locomotor activity. Stereotypy is considered by the software as an instable movement any time when repetitive movements are recorded in sequel readings, without alteration in the animals' mass center. The possible units of measurement to be considered are $\mathrm{mm}$ (millimeters), $\mathrm{cm}$ (centimeters) and in (inches).

\section{Tissue and homogenate preparation}

Animals were killed by decapitation 60 min after behavioral analyses. Brains were removed and hippocampus, prefrontal cortex, striatum and amygdala were homogenized (1:10, $\mathrm{w} / \mathrm{v}$ ) in SETH buffer, pH 7.4 (250 mM sucrose, 2 mM EDTA, $10 \mathrm{mM}$ Trizma base, $50 \mathrm{IU} / \mathrm{ml}$ heparin). Homogenates were centrifuged at $800 \times \mathrm{g}$ for 10 minutes and the supernatants were kept at -70 ㅇ $\mathrm{C}$ until they were used for enzyme activity determination.

\section{CK activity assay}

CK activity was measured in brain homogenates pre-treated with $0.625 \mu \mathrm{M}$ lauryl maltoside. The reaction mixture consisted of $60 \mu \mathrm{M}$ Tris- $\mathrm{HCl}, \mathrm{pH} 7.5$, containing $7 \mu \mathrm{M}$ phosphocreatine, $9 \mathrm{mM} \mathrm{MgSO}_{4}$ and approximately 0.4-1.2 $\mathrm{mg}$ protein in a final volume of $100 \mu \mathrm{L}$. After 15 min of preincubation at $37^{\circ} \mathrm{C}$, the reaction was started by the addition of $0.3 \mathrm{mmol}$ of ADP plus $0.08 \mu \mathrm{mol}$ of reduced glutathione.
The reaction was stopped after $10 \mathrm{~min}$ by the addition of 1 $\mu \mathrm{mol}$ of $\mathrm{p}$-hydroxymercuribenzoic acid. The creatine formed was estimated according to the colorimetric method of Hughes $(1962)^{42}$. The color was developed by the addition of $100 \mu \mathrm{L} 2 \% \mu$-naphtol and $100 \mu \mathrm{L} 0.05 \%$ diacetyl in a final volume of $1 \mathrm{~mL}$ and read spectrophotometrically after 20 $\min$ at $540 \mathrm{~nm}$. Results were expressed as $\mathrm{nmol} \times(\min x$ mg protein) ${ }^{-1}$.

\section{Respiratory chain enzyme activity}

ComplexI, or NADH dehydrogenase, was evaluated using the method described by Cassina and Radi $(1996)^{43}$ by the rate of NADH-dependent ferricyanide reduction at $420 \mathrm{~nm}$. The activity of succinate:ubiquinone oxidoreductase (complex II) was determined by the method described by Fischer and colleagues $(1985)^{44}$, following the decrease in absorbance due to the reduction of 2,6-dichloroindophenol at 600 $\mathrm{nm}$. Complex II-III activity was measured as cytochrome c reduction from succinate at $550 \mathrm{~nm}$ and $37 \circ \mathrm{O} \mathrm{C}$ according to the method of Birch-Machin and colleagues (1994) ${ }^{45}$. The activity of cytochrome c oxidase (complex IV) was assayed according to the method described by Rustin and colleagues $(1994)^{46}$, in which the decrease in absorbance due to the oxidation of previously reduced cytochrome $c$ at $550 \mathrm{~nm}$ is followed. The activities of the mitochondrial respiratory chain complexes were expressed as $\mathrm{nmoL} x$

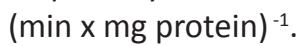

\section{Protein content}

Protein content was determined by the method described by Lowry and colleagues (1951) ${ }^{47}$ using bovine serum albumin as standard.

\section{Statistical analysis}

Data were analyzed using the software Statistical Package for the Social Sciences (SPSS Inc, Chicago, IL), version 18.0. Activities of $\mathrm{CK}$ and of the respiratory chain complexes were all fitted into a standard curve distribution, and were therefore subjected to parametric analyses. Groups were compared by one-way ANOVA, followed by posttest of Tukey. $P$-values $<0.05$ were considered statistically significant. Number of crossings, grooming behavior, and stereotypy data were not fitted into a standard curve distribution, and were analyzed by Kruskal-Wallis test, followed by Mann-Whitney comparisons between groups. $P$-values $<0.0125$ were considered statistically significant after Bonferroni corrections for multiple comparisons.

\section{Results}

\section{Open-field task}

KET significantly increased the number of crossings $(U=0$, $Z=-4.160, p<0.001$ ) when compared to the control group. 
However, this increase was not prevented by the treatment with AMA on the AMA+KET group $(U=42, Z=-1.732, p=$ 0.089, compared to SAL+KET; $U=6.5, Z=-3.782, p<0.001$, compared to AMA + SAL). No other differences were found between groups.

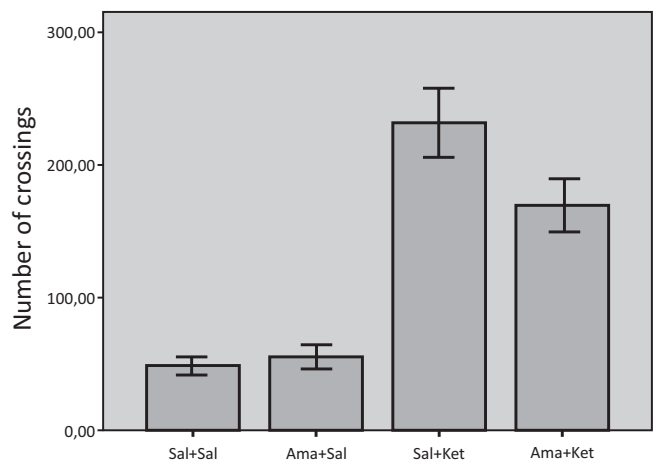

Graphic 1 Number of crossings

\section{Grooming behavior}

Grooming behavior was significantly reduced in SAL+KET (U = 26.5, $\mathrm{Z}=-2.636, p=0.008$ ) when compared to control. AMA treatment partially prevented this reduction given that AMA+KET group did not significantly differ from SAL+SAL ( $U$ $=31, Z=-2.377, p=0.017)$, but no difference was found between SAL+KET and AMA+KET ( $U=68, Z=-0.233, p=$ $0.816)$. No other differences were found between groups.

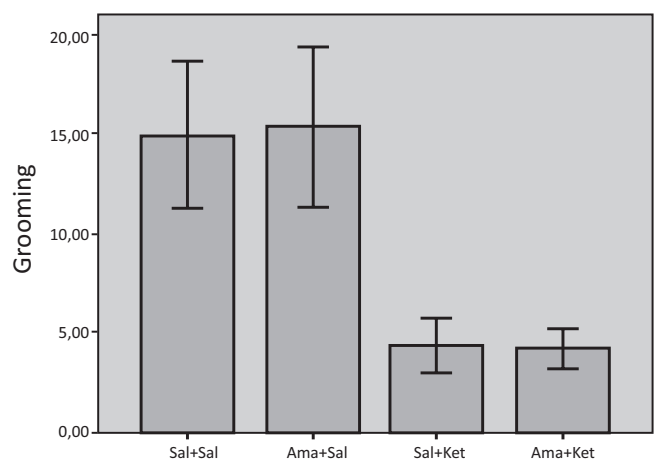

Graphic 2 Grooming behavior

Table 1 Behavioral data from rats in the KET-induced animal model of schizophrenia

\begin{tabular}{cccccc} 
& $\mathrm{SAL}+\mathrm{SAL}$ & $\mathrm{AMA}+\mathrm{SAL}$ & $\mathrm{SAL}+\mathrm{KET}$ & $\mathrm{AMA}+\mathrm{KET}$ & $\mathrm{p}^{*}$ \\
\hline Crossings a & 46 & 50.5 & 215 & 163 & $<$ \\
& $(32-69)$ & $(42.25-74.25)$ & $(159-264.25)$ & $(102.75-222.75)$ & 0.001 \\
Grooming a & 11.5 & 10 & 2.5 & 4 & 0.01 \\
& $(5-21.25)$ & $(3-28.75)$ & $(0.25-6.75)$ & $(0.25-7)$ & \\
Stereotipy a & 0 & 0 & 3 & 0 & 0.004 \\
& $(0-0)$ & $(0-0.75)$ & $(0-3)$ & $(0-2)$ & \\
\hline
\end{tabular}

${ }^{\text {a }}$ Data expressed as median (interquartile range).

*Independent samples Kruskal-Wallis test.

\section{Stereotypic movements}

KET significantly increased stereotypic movements when compared to control ( $U=24, Z=-3.323, p=0.001)$, and AMA treatment partially prevented this behavior, given that AMA+KET did not significantly differ from the control group $(U=42, Z=-2.44, p=0.015)$ or from $S A L+K E T(U=$ $58, Z=-0.965, p=0.335)$. No other differences were found between groups.

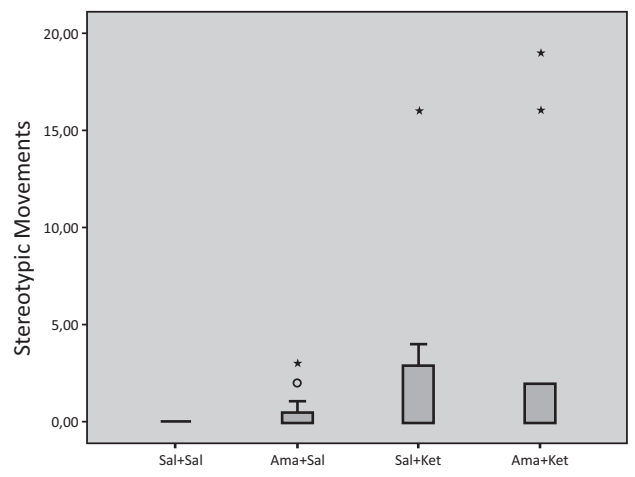

Graphic 3 Stereotypic movements

\section{CK activity}

Treatment with KET increased CK activity in the prefrontal cortex $(F(3,18)=8.253, p=0.001)$ and in striatum $(F(3$, $19)=8.251, p=0.001)$, when compared to the control group, and in the amygdala $(F(3,17)=10.983), p<0.001)$, when compared to AMA+SAL (Figure 1). This increase was prevented by AMA in prefrontal cortex and striatum, but not in the amygdala ( $p=0.323$, when compared to SAL+KET). In hippocampus, no differences could be found between groups. AMA treatment per se did not alter CK activity when compared to control.

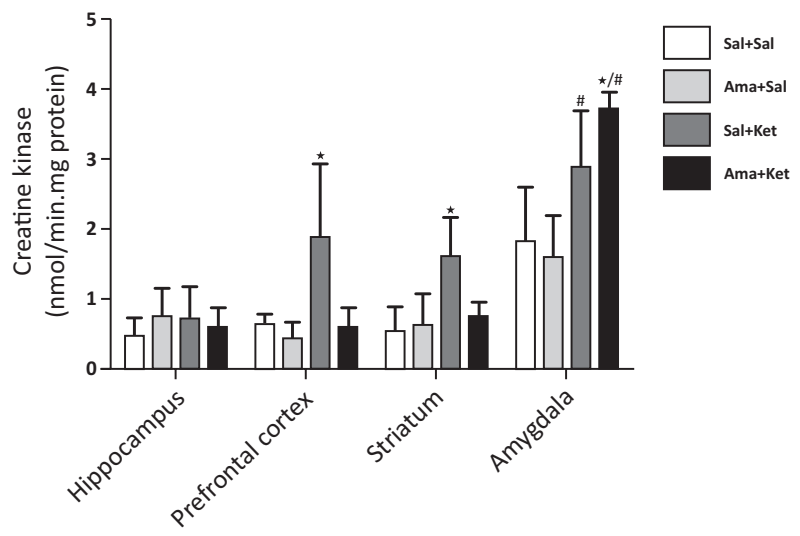

Figure 1 Creatine kinase activity was measured by a colorimetric method in hippocampus, prefrontal cortex, striatum and amygdala region. Data were analyzed by ANOVA followed by Tukey test ( $n$ = 5-7 per group). ${ }^{*}$ Different from SAL+SAL, $p<0.05$. \#Different from AMA+SAL, $p<0.05$. Results are expressed as $\mathrm{nmol} /(\mathrm{min} \mathrm{x}$ mg protein). 


\section{Complex I}

KET treatment per se did not alter complex I activity (Figure 2). However, when combined with AMA, it increased the enzyme activity in the striatum $(F(22,3)=2.948, p=$ $0.045)$ and in the amygdala $(F(3,15)=13.995, p<0.001)$. No further differences were found between groups in the hippocampus or in the prefrontal cortex.

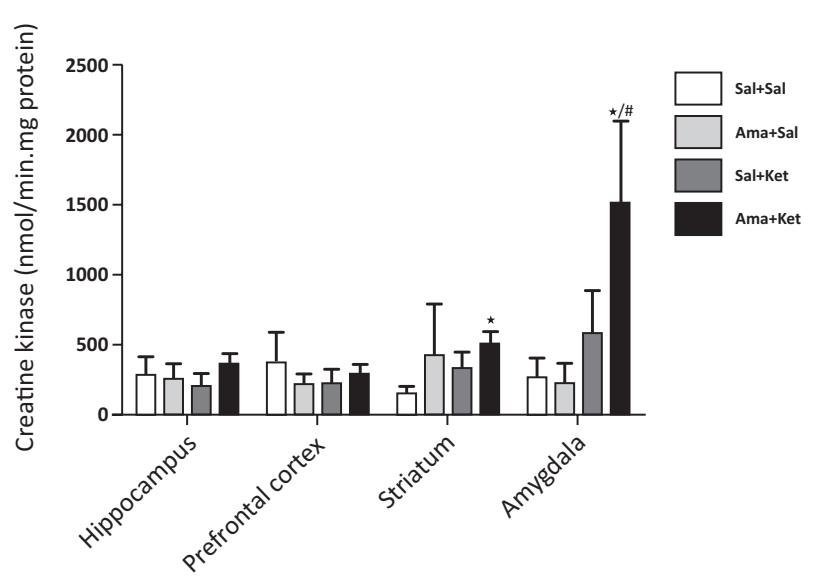

Figure 2 Complex I activity was measured in hippocampus, prefrontal cortex, striatum and amygdala region. Data were analyzed by ANOVA followed by Tukey test ( $n=5-7$ per group). *Different from SAL+SAL, $p<0.05$. \#Different from AMA+SAL, $p<0.05$. Results are expressed as $\mathrm{nmol} /$ ( $\min \times \mathrm{mg}$ protein).

\section{Complex II}

KET treatment increased the activity of complex II in the striatum $(F(3,21)=7.153, p=0.002)$, whereas the combination of AMA+KET increased this activity in hippocampus $(F(3,23)=5.171, p=0.007)$, prefrontal cortex $(F(3,18)=5.041, p=0.01)$, and striatum $(F(3,21)=7.153$, $p=0.002)$. No differences were found between groups in the amygdala.

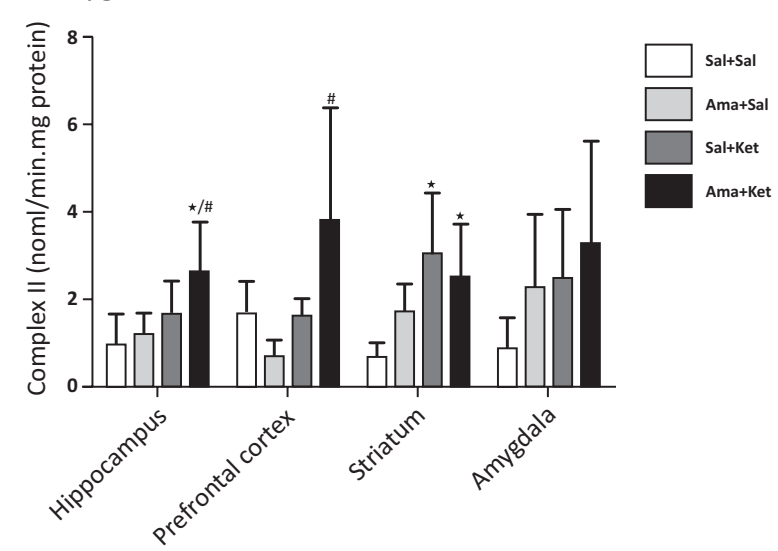

Figure 3 Complex II activity was measured in hippocampus, prefrontal cortex, striatum and amygdala region. Data were analyzed by ANOVA followed by Tukey test ( $n=5-7$ per group). *Different from $S A L+S A L$, $p<0.05$. \#Different from AMA+SAL, $p<0.05$. Results are expressed as $\mathrm{nmol} /$ (min $\mathrm{x} \mathrm{mg}$ protein).

\section{Complex II-III}

Whereas KET alone did not change complex II-III activity in any of the brain regions, AMA+KET increased its activity in the hippocampus $(F(3,22)=5.166, p=0.007)$ and in the amygdala $(F(3,18)=5.54, p=0.07)$. No differences were found between groups in the prefrontal cortex and in the striatum.



Figure 4 Complex II-III activity was measured in hippocampus, prefrontal cortex, striatum and amygdala region. Data were analyzed by ANOVA followed by Tukey test ( $n=5-7$ per group). *Different from SAL+SAL, $p<0.05$. \#Different from AMA+SAL, $p<$ 0.05 . Results are expressed as $\mathrm{nmol} /$ (min $\times \mathrm{mg}$ protein).

\section{Complex IV}

AMA+KET treatment increased complex IV activity in the hippocampus $(F(3,16)=8.31, p=0.001)$ and in the striatum $(F(3,14)=5.087, p=0.014)$, whereas KET treatment per se had no effect on the enzyme activity. No differences between groups were found in the prefrontal cortex and in the amygdala.

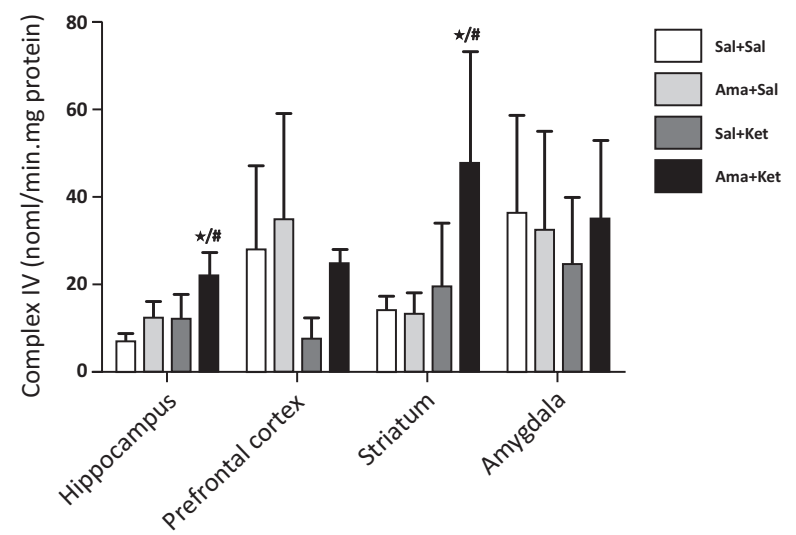

Figure 5 Complex IV activity was measured in hippocampus, prefrontal cortex, striatum and amygdala region. Data were analyzed by ANOVA followed by Tukey test ( $n=5-7$ per group). ${ }^{*}$ Different from $\mathrm{SAL}+\mathrm{SAL}, p<0.05$. \#Different from AMA+SAL, $p<0.05$. Results are expressed as $\mathrm{nmol} /$ ( $\mathrm{min} \times \mathrm{mg}$ protein). 


\section{Discussion}

Among several newly tested drugs for SZ, nonselective NMDA antagonists appear to have an important potential for its successful treatment. In our animal model of SZ induced by KET treatment, AMA partially prevented the KET-induced stereotypy and KET-induced reduction of grooming behavior, as well as prevented the increase in CK activity in prefrontal cortex and in striatum. However, AMA did not prevent KET-induced increase in complex II activity, and acted in a synergistic way with KET to increase the activities of other respiratory chain enzymes in different brain regions. These results suggest that AMA is not fully effective in preventing KET effects in this animal model of $\mathrm{SZ}$, and would indicate a synergic action of both drugs in the modulation of the respiratory chain enzymes.

Sub-anesthetic KET administrations have been consistently employed as a valid animal model of SZ. Given its action as an NMDA antagonist, it can produce hallucinations and paranoia in humans ${ }^{48}$, which are similar to positive symptoms. As discussed elsewhere ${ }^{41,49,50}$, this model mimics both positive and negative symptoms of the disorder, as well as its cognitive impairments, which makes it suitable for the test of potential new drugs for the treatment of SZ. Of note, KET effects include changes in dopaminergic, glutamatergic and serotoninergic systems, which ultimately lead to increased hippocampal D2 receptors, decreased glutamatergic receptors in the PFC, and increased density of dopamine and serotonin transporters in hippocampus, striatum and $\mathrm{PFC}^{36}$. Each of these effects may differentially influence KET-induced behavioral features, and may be responsible for the modulation of mitochondrial functions, as previously shown ${ }^{31}$.

Behavioral testing showed that KET significantly increased the number of crossings assessed by the open-field test, as well as reduced grooming behavior. These KET-induced features have also been reported in other studies ${ }^{31,32}$, and suggest relevant face validity for this animal model of SZ. However, our results show that AMA could not fully prevent these behavioral effects, which may account for a lack of predictive validity for this model. KET also significantly increased stereotypic movements, which was only partially prevented by AMA. Clinical data points to an efficacy of memantine and AMA in improving positive and negative symptoms in clozapine treatment refractory patients with $\mathrm{SZ}^{37,39}$, which suggests that the effects of AMA might be more related to reversal of symptoms in a long-term course of psychosis as an adjunctive treatment to antipsychotics. As far as we know, AMA is an NMDA antagonist and could theoretically induce psychotic symptoms or even worsen them in patients with $\mathrm{SZ}^{51}$. Clinical data show that memantine and AMA act in very unique and unstable ways in glutamatergic, dopaminergic and serotoninergic pathways, and their use in monotherapy in patients with neuropsychiatric disorders such as SZ, Parkinson disease, and bipolar disorder could indeed worsen psychotic symptoms $\mathrm{s}^{52,53}$. On the other hand, as AMA appears to act via several pharmacological mechanisms rather than uniquely on NMDA receptors, none of them has been identified as its main mode of action, and it is not clear which of these mechanisms is the most relevant at the therapeutic dose of the drug. Moreover, a KET treatment mimic mostly the acute phase of the disease, and it is possible that AMA may be more efficient in the treatment of chronic SZ. Further studies with different dosages of AMA in different models of SZ are necessary to elucidate this hypothesis ${ }^{54-57}$.

The lack of efficacy of AMA in preventing KET effects could also be seen in the respiratory chain complexes, where in most cases the alteration was found only in the combined AMA+KET group, and not in rats treated only with KET. Interestingly, there seems to be a synergic effect of both drugs in all of the enzymes. This may be explained by the fact that both drugs are NMDA antagonists, and it is possible that this specific effect is an important modulator of the respiratory chain enzyme activities assessed in this model.

Of note, AMA presents other mechanisms of action that account for its neuroprotective effects, which include inhibition of the release of microglial pro-inflammatory factors such as tumor necrosis factor alpha (TNF- $\alpha$ ) and other interleukines, as well as an increase in the expression of neurotrophic factors such as GDNF and BDNF in astroglia58,59. In fact, it has been reported that the AMAinduced NMDA receptor inhibition is independent of its neuroprotective effects58. Moreover, mitochondrial effects induced by memantine are mostly or entirely mediated independent of NMDA channel modulation40. These data emphasizing other AMA mechanisms of action justify its use in preventing KET-induced effects, even though both of these drugs are NMDA antagonists, and awaits further experiments to clarify the relevance of these different effects on its efficacy for the treatment of SZ.

Mitochondria dysfunction has been reported as a major pathophysiological aspect of SZ19,20,60. Likewise, mitochondrial dysfunction has been investigated after KET administration to rats31. A previous study from our group has shown that KET treatment per se not only increased complex I activity in the striatum, hippocampus and in PFC, but also increased the activities of complex II-III in the striatum, and of complex IV in the hippocampus and striatum31. However, our results showed no such differences between groups. We found a synergic effect of KET+AMA in increasing the activities of complex I in the amygdala and striatum, of complex II and IV in the hippocampus and striatum, and of complex II-III in the hippocampus and in the amygdala. Treatment of KET per se only increased complex II activity in striatum, which was not seen in our previous study31. Discrepancies between the studies might be related to differences in the time between the last injection, behavioral testing and decapitation. In summary, the enhanced activity of mitochondrial respiratory chain 
complexes found in our samples may reflect an increased energetic demand of cellular functions in these situations.

Such an increased energetic demand is also reflected by our results on CK. CK reversibly catalyzes the conversion of creatine and consumes ATP to create phosphocreatine and $A D P$, thus acting to maintain energy homeostasis. Our results showing increased CK activity in PFC, striatum and amygdala are in accordance with a previous study ${ }^{32}$, and suggest a higher ATP demand on these tissues. Moreover, AMA successfully prevented this increase in PFC and striatum, not presenting this effect on amygdala. It is possible that this AMA-induced prevention in CK activity may be associated with the prevention of stereotypic movements, but so far we cannot rule out other possible mechanisms by which it could interfere on KET-induced effects.

Some limitations need to be taken into account when analyzing our data. First of all, even though KET treatment has been successfully employed as an animal model of SZ, it presents obvious limitations when considering the complexity of the disorder and the simplicity of mimicking it with an NMDA antagonist administration. Nonetheless, such a limitation is common to almost every animal model there is, and warrants further research on the development of novel and more reliable animal models of human disorders. Moreover, the efficacy of AMA in preventing schizophrenic-like behaviors would be better assessed in other animal models of SZ, rather than in one induced by an NMDA antagonist. In this case, we consider that other mechanisms of action from KET and AMA are crucial for their effects, thus justifying their combined use in this study.

\section{Conclusions}

In summary, we showed that AMA partially prevented KETinduced stereotypic movements, KET-induced reduction in grooming behavior, and prevented the increase in CK activity. However, it had no effect on KET-induced locomotor activity and on the modulation of mitochondrial chain complexes. Based on clinical data pointing to an efficacy of AMA in treating patients, our results suggest that other animal models of SZ should be employed in the study of AMA as a potential therapeutic drug for this disorder.

\section{References}

1. Stefan M, Travis M, Murray R. An Atlas of Schizophrenia. London: Parthenon Publishing Group; 2002.

2. Bowie CR, Harvey PD. Cognitive deficits and functional outcome in schizophrenia. Neuropsychiatr Dis Treat. 2006 Dec;2(4):531-6. PubMed PMID: 19412501.

3. Jones PB, Buckley PF. Schizophrenia: Churchill Livingstone, Elsevier; 2006.

4. Lindenmayer JP. Treatment refractory schizophrenia. Psychiatr Q. 2000 Winter;71(4):373-84. PubMed PMID: 11025914.

5. Ross CA, Margolis RL, Reading SA, Pletnikov M, Coyle JT. Neurobiology of schizophrenia. Neuron. 2006 Oct 5;52(1):139-53. Review. PubMed PMID: 17015232.

6. Gama CS, Salvador M, Andreazza AC, Kapczinski F, Silva Belmonte-deAbreu P. Elevated serum superoxide dismutase and thiobarbituric acid reactive substances in schizophrenia: a study of patients treated with haloperidol or clozapine. Prog Neuropsychopharmacol Biol Psychiatry. 2006 May;30(3):512-5. Epub 2006 Jan 19. PubMed PMID: 16426720.

7. Gama CS, Andreazza AC, Kunz M, Berk M, Belmonte-de-Abreu PS, Kapczinski F. Serum levels of brain-derived neurotrophic factor in patients with schizophrenia and bipolar disorder. Neurosci Lett. 2007 Jun 8;420(1):45-8. Epub 2007 Apr 4. PubMed PMID: 17442489.

8. Gama CS, Salvador M, Andreazza AC, Lobato MI, Berk M, Kapczinski $\mathrm{F}$, et al. Elevated serum thiobarbituric acid reactive substances in clinically symptomatic schizophrenic males. Neurosci Lett. 2008 Mar 15;433(3):270-3. doi: 10.1016/j.neulet.2008.01.018. Epub 2008 Jan 16. PubMed PMID: 18255229.

9. Gama CS, Berk M, Andreazza AC, Kapczinski F, Belmonte-de-Abreu P. Serum levels of brain-derived neurotrophic factor and thiobarbituric acid reactive substances in chronically medicated schizophrenic patients: a positive correlation. Rev Bras Psiquiatr. 2008 Dec;30(4):33740. PubMed PMID: 19142408.
10. Bray NJ, Leweke FM, Kapur S, Meyer-Lindenberg A. The neurobiology of schizophrenia: new leads and avenues for treatment. Curr Opin Neurobiol. 2010;20(6):810-5. doi: 10.1016/j.conb.2010.09.008. Epub 2010 Oct 8. Review. PubMed PMID: 20934321.

11. Bitanihirwe BK, Woo TU. Oxidative stress in schizophrenia: an integrated approach. Neurosci Biobehav Rev. 2011 Jan;35(3):878-93. doi: 10.1016/j.neubiorev.2010.10.008. Epub 2010 Oct 23. Review. PubMed PMID: 20974172; PubMed Central PMCID: PMC3021756.

12. van Haren NE, Cahn W, Hulshoff Pol HE, Kahn RS. The course of brain abnormalities in schizophrenia: can we slow the progression? J Psychopharmacol. 2012 May;26(5 Suppl):8-14. doi: 10.1177/0269881111408964. Epub 2011 Jul 5. Review. PubMed PMID: 21730018.

13. Cahn W, Hulshoff Pol HE, Lems EB, van Haren NE, Schnack HG, van der Linden JA, Schothorst PF, van Engeland H, Kahn RS. Brain volume changes in first-episode schizophrenia: a 1-year follow-up study. Arch Gen Psychiatry. 2002 Nov;59(11):1002-10. PubMed PMID: 12418933.

14. DeLisi LE, Sakuma M, Maurizio AM, Relja M, Hoff AL. Cerebral ventricular change over the first 10 years after the onset of schizophrenia. Psychiatry Res. 2004 Jan 15;130(1):57-70. PubMed PMID: 14972368.

15. Lieberman J, Chakos M, Wu H, Alvir J, Hoffman E, Robinson D, et al. Longitudinal study of brain morphology in first episode schizophrenia. Biol Psychiatry. 2001 Mar 15;49(6):487-99. PubMed PMID: 11257234.

16. Ho BC, Andreasen NC, Nopoulos P, Arndt S, Magnotta V, Flaum M. Progressive structural brain abnormalities and their relationship to clinical outcome: a longitudinal magnetic resonance imaging study early in schizophrenia. Arch Gen Psychiatry. 2003 Jun;60(6):585-94. PubMed PMID: 12796222.

17. Beal MF. Does impairment of energy metabolism result in excitotoxic neuronal death in neurodegenerative illnesses? Ann Neurol. 1992 Feb;31(2):119-30. Review. PubMed PMID: 1349466. 
18. Kaur P, Radotra B, Minz RW, Gill KD. Impaired mitochondrial energy metabolism and neuronal apoptotic cell death after chronic dichlorvos (OP) exposure in rat brain. Neurotoxicology. 2007 Nov;28(6):1208-19. Epub 2007 Aug 7. PubMed PMID: 17850875.

19. Clay HB, Sillivan S, Konradi C. Mitochondrial dysfunction and pathology in bipolar disorder and schizophrenia. Int J Dev Neurosci. 2011 May;29(3):311-24. doi: 10.1016/j.ijdevneu.2010.08.007. Epub 2010 Sep 15. Review. PubMed PMID: 20833242.

20. Ben-Shachar D. Mitochondrial dysfunction in schizophrenia: a possible linkage to dopamine. J Neurochem. 2002 Dec;83(6):1241-51. Review. PubMed PMID: 12472879.

21. Karry R, Klein E, Ben Shachar D. Mitochondrial complex I subunits expression is altered in schizophrenia: a postmortem study. Biol Psychiatry. 2004 Apr 1;55(7):676-84. PubMed PMID: 15038995.

22. Maurer I, Zierz S, Möller H. Evidence for a mitochondrial oxidative phosphorylation defect in brains from patients with schizophrenia. Schizophr Res. 2001 Mar 1;48(1):125-36. PubMed PMID: 11278159.

23.Ji B, La Y, Gao L, Zhu H, Tian N, Zhang M, et al. A comparative proteomics analysis of rat mitochondria from the cerebral cortex and hippocampus in response to antipsychotic medications. J Proteome Res. 2009 Jul;8(7):3633-41. doi: 10.1021/pr800876z. PubMed PMID: 19441803.

24. Davis KL, Charney D, Coyle JT, Nemeroff C, editors. Neuropsychopharmacology: the fifth generation of progress editors [Internet]. Pennsylvania: Lippincott Williams \& Wilkins; 2002. Chapter 50, Animal models relevant to schizophrenia disorders; [cited 2011 Jan 1]; p. 689-701. Available from: http://www.acnp.org/publications/ neuro5thgeneration.aspx

25. Allen RM, Young SJ. Phencyclidine-induced psychosis. Am J Psychiatry. 1978 Sep; 135(9):1081-4. PubMed PMID: 696930.

26. Becker A, Grecksch G. Ketamine-induced changes in rat behaviour: a possible animal model of schizophrenia. Test of predictive validity. Prog Neuropsychopharmacol Biol Psychiatry. 2004 Dec;28(8):1267-77. PubMed PMID: 15588753.

27. Lahti AC, Holcomb HH, Medoff DR, Tamminga CA. Ketamine activates psychosis and alters limbic blood flow in schizophrenia. Neuroreport. 1995 Apr 19;6(6):869-72. PubMed PMID: 7612873.

28. Lahti AC, Koffel B, LaPorte D, Tamminga CA. Subanesthetic doses of ketamine stimulate psychosis in schizophrenia. Neuropsychopharmacology. 1995 Aug;13(1):9-19. PubMed PMID: 8526975.

29. Lahti AC, Weiler MA, Tamara Michaelidis BA, Parwani A, Tamminga CA. Effects of ketamine in normal and schizophrenic volunteers. Neuropsychopharmacology. 2001 Oct;25(4):455-67. PubMed PMID: 11557159.

30. Newcomer JW, Farber NB, Jevtovic-Todorovic V, Selke G, Melson AK, Hershey T, Craft S, Olney JW. Ketamine-induced NMDA receptor hypofunction as a model of memory impairment and psychosis. Neuropsychopharmacology. 1999 Feb;20(2):106-18. PubMed PMID: 9885791.

31. de Oliveira L, Fraga DB, De Luca RD, Canever L, Ghedim FV, Matos MP, et al. Behavioral changes and mitochondrial dysfunction in a rat model of schizophrenia induced by ketamine. Metab Brain Dis. 2011 Mar;26(1):6977. doi: 10.1007/s11011-011-9234-1. Epub 2011 Feb 18. PubMed PMID: 21331561.
32. Canever L, Oliveira L, D’Altoé de Luca R, Correa PT, de B Fraga D, Matos MP, Scaini G, Quevedo J, Streck EL, Zugno Al. A rodent model of schizophrenia reveals increase in creatine kinase activity with associated behavior changes. Oxid Med Cell Longev. 2010 NovDec;3(6):421-7. Epub 2010 Nov 1. PubMed PMID: 21270541.

33.Bubeníková-Valesová V, Horácek J, Vrajová M, Höschl C. Models of schizophrenia in humans and animals based on inhibition of NMDA receptors. Neurosci Biobehav Rev. 2008 Jul;32(5):1014-23. doi: 10.1016/j. neubiorev.2008.03.012. Epub 2008 Apr 8. Review. PubMed PMID: 18471877.

34. Lipska BK, Weinberger DR. To model a psychiatric disorder in animals: schizophrenia as a reality test. Neuropsychopharmacology. 2000 Sep;23(3):223-39. Review. PubMed PMID: 10942847.

35. de Oliveira L, Spiazzi CM, Bortolin T, Canever L, Petronilho F, Mina FG, Dal-Pizzol F, Quevedo J, Zugno Al. Different sub-anesthetic doses of ketamine increase oxidative stress in the brain of rats. Prog Neuropsychopharmacol Biol Psychiatry. 2009 Aug 31;33(6):1003-8. doi: 10.1016/j.pnpbp.2009.05.010. Epub 2009 May 18. PubMed PMID: 19454299.

36. Becker A, Peters B, Schroeder H, Mann T, Huether G, Grecksch G. Ketamine-induced changes in rat behaviour: A possible animal model of schizophrenia. Prog Neuropsychopharmacol Biol Psychiatry. 2003 Jun;27(4):687-700. PubMed PMID: 12787858.

37. de Lucena D, Fernandes BS, Berk M, Dodd S, Medeiros DW, Pedrini M, Kunz M, Gomes FA, Giglio LF, Lobato MI, Belmonte-de-Abreu PS, Gama CS. Improvement of negative and positive symptoms in treatmentrefractory schizophrenia: a double-blind, randomized, placebocontrolled trial with memantine as add-on therapy to clozapine. J Clin Psychiatry. 2009 Oct;70(10):1416-23. doi: 10.4088/JCP.08m04935gry. Erratum in: J Clin Psychiatry. 2011 Aug;72(8):1157. PubMed PMID: 19906345.

38. Gama CS, Lucena DD, Cruz C, Lobato MI, Belmonte-de-Abreu PS. Improvement of schizophrenia negative and positive symptoms with amantadine as add-on therapy to antipsychotics: a case series. Rev Bras Psiquiatr. 2010 Jun;32(2):193-4. PubMed PMID: 20658059.

39. de Lucena DF, Pinto JP, Hallak JE, Crippa JA, Gama CS. Short-Term Treatment of Catatonia With Amantadine in Schizophrenia and Schizoaffective Disorder. J Clin Psychopharmacol. 2012 Aug;32(4):56972. doi: 10.1097/JCP.0b013e31825ebf6e. PubMed PMID: 22760350.

40. McAllister J, Ghosh S, Berry D, Park M, Sadeghi S, Wang KX, et al. Effects of memantine on mitochondrial function. Biochem Pharmacol. 2008 Feb 15;75(4):956-64. Epub 2007 Oct 23. PubMed PMID: 18053965.

41. Hunt MJ, Raynaud B, Garcia R. Ketamine dose-dependently induces high-frequency oscillations in the nucleus accumbens in freely moving rats. Biol Psychiatry. 2006 Dec 1;60(11):1206-14. Epub 2006 May 2. PubMed PMID: 16650831.

42. Hughes BP. A method for the estimation of serum creatine kinase and its use in comparing creatine kinase and aldolase activity in normal and pathological sera. Clin Chim Acta. 1962 Sep;7:597-603. PubMed PMID: 13955534.

43. Cassina A, Radi R. Differential inhibitory action of nitric oxide and peroxynitrite on mitochondrial electron transport. Arch Biochem Biophys. 1996 15; 328(2):309-16. PubMed PMID: 8645009.

44. Fischer JC, Ruitenbeek W, Berden JA, Trijbels JM, Veerkamp JH, Stadhouders AM, et al. Differential investigation of the capacity of succinate oxidation in human skeletal muscle. Clin Chim Acta. 1985 Nov 29;153(1):23-36. PubMed PMID: 300647. 
45. Birch-Machin MA, Briggs HL, Saborido AA, Bindoff LA, Turnbull DM. An evaluation of the measurement of the activities of complexes I-IV in the respiratory chain of human skeletal muscle mitochondria. Biochem Med Metab Biol. 1994 Feb; 51(1):35-42. PubMed PMID: 8192914.

46. Rustin P, Chretien D, Bourgeron T, Gérard B, Rötig A, Saudubray JM, Munnich $A$. Biochemical and molecular investigations in respiratory chain deficiencies. Clin Chim Acta. 1994 Jul;228(1):35-51. Review. PubMed PMID: 7955428.

47. Lowry OH, Rosenbrough NJ, Farr AL, Randall RJ. Protein measurement with the Folin phenol reagent. J Biol Chem. 1951 Nov;193(1):265-75. PubMed PMID: 14907713.

48. Malhotra AK, Pinals DA, Adler CM, Elman I, Clifton A, Pickar D, et al. Ketamine-induced exacerbation of psychotic symptoms and cognitive impairment in neuroleptic-free schizophrenics. Neuropsychopharmacology. 1997 Sep;17(3):141-50. PubMed PMID: 9272481.

49. Littlewood CL, Jones N, O’Neill MJ, Mitchell SN, Tricklebank M, Williams SC. Mapping the central effects of ketamine in the rat using pharmacological MRI. Psychopharmacology (Berl). 2006 May;186(1):6481. Epub 2006 Mar 21. Erratum in: Psychopharmacology (Berl). 2006 Oct;188(2):261-2. PubMed PMID: 16550385.

50. Takeyama K, Yoshikawa M, Oka T, Kawaguchi M, Suzuki T, Hashimoto A. Ketamine enhances the expression of serine racemase and $D$-amino acid oxidase mRNAs in rat brain. Eur J Pharmacol. 2006 Jul 1;540(13):82-6. Epub 2006 Apr 28. PubMed PMID: 16716293.

51. Lieberman JA, Papadakis K, Csernansky J, Litman R, Volavka J, Jia XD, Gage A; MEM-MD-29 Study Group. A randomized, placebocontrolled study of memantine as adjunctive treatment in patients with schizophrenia. Neuropsychopharmacology. 2009 Apr;34(5):13229. doi: 10.1038/npp.2008.200. Epub 2008 Nov 12. PubMed PMID: 19005465.
52. Smith EJ. Amantadine-induced psychosis in a young healthy patient. Am J Psychiatry. 2008 Dec;165(12):1613. doi: 10.1176/appi. ajp.2008.08081228. PubMed PMID: 19047338.

53. Canan F, Ataoglu A. Memantine-related psychotic symptoms in a patient with bipolar disorder. J Clin Psychiatry. 2010 Jul;71(7):957. doi: 10.4088/JCP.09I05802gry. PubMed PMID: 20667296.

54. Seeman P, Caruso C, Lasaga M. Memantine agonist action at dopamine D2High receptors. Synapse. 2008 Feb;62(2):149-53. PubMed PMID: 18000814.

55. Fusar-Poli P, Pellegrini F, Cortesi M. Memantine as a neuroprotective agent in early phases of psychosis. Med Hypotheses. 2007;68(2):45960. Epub 2006 Sep 26. PubMed PMID: 17005328.

56. Huey ED, Dustin IH, Overman GP, Mirza N, Sunderland T. Development of subtle psychotic symptoms with memantine: a case report. J Clin Psychiatry. 2005 May;66(5):658-9. PubMed PMID: 15889961

57. Riederer P, Lange KW, Kornhuber J, Danielczyk W. Pharmacotoxic psychosis after memantine in Parkinson's disease. Lancet. 1991 Oct;338(8773):1022-3. PubMed PMID: 1681331.

58. Ossola B, Schendzielorz N, Chen SH, Bird GS, Tuominen RK, Männistö PT, Hong JS. Amantadine protects dopamine neurons by a dual action: reducing activation of microglia and inducing expression of GNDF in astroglia. Neuropharmacology. 2011 Sep;61(4):574-82. doi: 10.1016/j. neuropharm.2011.04.030. Epub 2011 May 11. PubMed PMID: 21586298.

59. Rogóz Z, Skuza G, Legutko B. Repeated co-treatment with fluoxetine and amantadine induces brain-derived neurotrophic factor gene expression in rats. Pharmacol Rep. 2008 Nov-Dec;60(6):817-26. PubMed PMID: 19211973.

60. Ben-Shachar D, Laifenfeld D. Mitochondria, synaptic plasticity, and schizophrenia. Int Rev Neurobiol. 2004;59:273-96. Review. PubMed PMID: 15006492. 